\title{
Two new foliicolous species of Enterographa (Roccellaceae) from Kenya
}

\author{
Kumelachew YESHITELA, Eberhard FISCHER, \\ Dorothee KILLMANN and Emmanuël SÉRUSIAUX
}

\begin{abstract}
Enterographa fellhaneroides and E. meklitiae are described as new to science from Kakamega Forest in Western Kenya. The latter overgrows the thallus of a foliicolous non-filamentous Coenogonium and the former most probably has the same ecology. Both species appear to be closely related to E. brezhonega and E. epiphyllum.
\end{abstract}

Key words: Coenogonium, Enterographa fellhaneroides, Enterographa meklitiae, lichens, Plectocarpon, Sclerophyton

\section{Introduction}

The lichen genus Enterographa Fée (Roccellaceae) has been expertly monographed by Sparrius (2004) and is characterized by the following characters: crustose growth habit, photobiont Trentepohlia or Phycopeltis, rounded to elongate or punctiform ascomata, most usually immersed in the thallus, exciple poorly developed, hamathecium of branched and anastomosing paraphysoids, ellipsoid to cylindrical-clavate asci of the Opegrapha-type, ascospores usually fusiform with thin septa and perispore, without enlarged terminal cells, conidiomata punctiform, and bacilliform or filiform microconidia. As circumscribed, the genus comprises 35 species, while the related genus Sclerophyton Eschw. includes species with macrocephalic ascospores with relatively thick septa and ascomata included in pseudostromata, with well-known and widespread species such as Enterographa elegans (Eschw.) Tuck, and E.

K. Yeshitela, E. Fischer and D. Killmann: Institute for Integrated Natural Sciences, Department of Biology, University of Koblenz-Landau, Universitätstraße I, D-56070 Koblenz, Germany.

E. Sérusiaux (corresponding author): Plant Taxonomy \& Conservation Biology Unit, University of Liège, Sart Tilman B22, B-4000 Liège, Belgium. Email: e.serusiaux@ulg.ac.be extenuatum (Nyl.) Redinger being transferred to Sclerophyton. Since the monograph by Sparrius (2004), 8 further new species have been described in the genus Enterographa and one species transferred into it (Ertz et al. 2005; Sparrius et al. 2006; Aptroot et al. 2007; Cáceres 2007; Sparrius \& Aptroot 2007; Sparrius \& Björk 2008; Jagadeesh Ram et al. 2008).

In spite of several detailed studies (Grube 1998; Myllys et al. 1999; Tehler 1990; Tehler et al. 1997) generic delimitation within the Roccellaceae is unsatisfactory and several genera are most probably polyphyletic or paraphyletic (D. Ertz, pers. comm.). A detailed phylogenetic study of two genes by Tehler \& Irestedt (2007) could even demonstrate parallel evolution of the fruticose growth form in the supposedly wellcircumscribed genera Roccella and Roccellina. The recent inclusion of Chiodecton epiphyllum Sérus., a species growing over a foliicolous species of Coenogonium in Papua New Guinea and the Neotropics, in Enterographa as a "better solution" than its earlier assignment to Plectocarpon Fée, shows that more data should be gathered to reach a wellsupported delimitation of the genus (Ertz et al. 2005).

Santesson (1952) recognized three foliicolous species of Enterographa. Since then 
Vězda (1975), Sérusiaux (1984), Lücking (1991), Sérusiaux (in Aptroot et al. 1995), Lücking \& Matzer (1996), Matzer (1996), Lücking et al. (1998), Herrera-Campos \& Lücking (2002), Lücking et al. (2003), Lücking \& Henssen (in Sparrius 2004) and Sparrius \& Björk (2008) described further new species. A total of 15 foliicolous species of Enterographa are currently known, including 2 lichenicolous fungi on foliicolous lichens (Sparrius 2004; Ertz et al. 2005); most of them distributed in the Neotropics and eastern Palaeotropics. Only two species (E. multiseptata and E. vezdai) have so far been recorded from the African continent.

Here we describe two further foliicolous species belonging to Enterographa, discovered by the first author in Kakamega Forest (W Kenya) in August 2006. One was clearly overgrowing the thallus of a species of Coenogonium and the second most probably had the same ecology.

\section{Materials and Methods}

Morphological characters were studied on dry specimens under a dissecting microscope. Anatomical characters were measured using light and interference contrast microscopy on hand-cut sections and squash preparations mounted in water. Water solution of $\mathrm{KOH}$ $(10 \%)$ and lactophenol-cotton blue were used for detailed observation of asci and hamathecial elements. Amyloidy of the tholus of asci and hymenium were tested with Lugol's solution.

\section{The study site}

Kakamega Forest is located in Shinyalu Division of the Kakamega District in the Western Province of Kenya. It is situated about $40 \mathrm{~km}$ north-west of Lake Victoria between $0^{\circ} 10^{\prime}$ and $0^{\circ} 21^{\prime} \mathrm{N}$ latitude and $34^{\circ} 47^{\prime}$ and $34^{\circ} 58^{\prime} \mathrm{E}$ longitude and is made up of a main forest block covering 8500 ha surrounded by five forest fragments of various sizes (130-1400 ha; Farwig et al. 2006). The vegetation consists of a mosaic of primary rainforest, secondary forests at different stages of development, swamp and riverine forest, selectively logged forest, plantations of indigenous and exotic tree species, natural glades, and clearings resulting from anthropogenic disturbance (Tattersfield et al. 2001; Althof 2005). Kakamega Forest is the easternmost patch of the equatorial forests distributed over the Congo basin and the only tropical rainforest with a mixture of GuineoCongolian and afromontane species in Kenya (Althof 2005).

\section{The Species}

\section{Enterographa fellhaneroides Yeshitela, Eb. Fisch., Killmann \& Sérus. sp. nov.}

Differt ab omnibus speciebus foliicolis generis Enterographa ascomata apothecioideis vel breve lirelliformibus, disco fusco cum margine albido et ascosporibus 6-septatis fusiformibus apicibusque rotundatis. Enterographa brezhonega differt ab E. fellhaneroides ascomata longe lirelliformibus saepe ramificatis et disco atrofusco. Enterographa seawardii differt sporibus 7-11-septatis anguste fusiformibus et thallo cum Pd+ luteo.

Typus: Kenya, Western Province, Kakamega Forest, $00^{\circ} 21^{\prime} .276^{\prime \prime} \mathrm{N}$ and $034^{\circ} 51^{\prime} .519^{\prime \prime} \mathrm{E}, 1609 \mathrm{~m}$, on living leaves of Dracaena fragrans, 14 August 2006, Yeshitela 349 (LG-holotypus).

\section{(Figs 1 \& 2)}

Thallus absent, ascomata overgrowing the thallus of a non-filamentous Coenogonium which is continuous, smooth, greyish green, usually with a whitish prothallus, photobiont Trentepohlia with cells angular-rounded, 12-20 × 5-8 $\mu \mathrm{m}$.

Ascomata sessile, 土aggregated, rounded to shortly lirelliform, constricted at base, $0 \cdot 2$ $0.8 \mathrm{~mm}$ diam., rarely up to $0.6 \mathrm{~mm}$ long, 50-60 $\mu \mathrm{m}$ high; disc exposed, pale to dark brown; margin 40-50 $\mu \mathrm{m}$ thick, slightly raised, whitish. Excipulum 10-15 $\mu \mathrm{m}$ wide, formed by densely interwoven hyphae filled with large crystals, hyaline or pale straw in section. Hypothecium 120-155 $\mu \mathrm{m}$ high including a 100-130 $\mu \mathrm{m}$ socle (formed by densely intricate hyphae filled with large, angular and hyaline oxalate crystals), hyaline, $\mathrm{K}-$. Hymenium 50-75 $\mu \mathrm{m}$ high, light brown in the upper part (c. $25 \mu \mathrm{m})$, otherwise hyaline, I+ blue, rapidly turning red, KI+ blue. Epithecium 5-8 $\mu \mathrm{m}$ high, orange-brown; $\mathrm{K}-$. Hamathecium of branched and anastomosing paraphysoids, c. $1.5 \mu \mathrm{m}$ thick, not swollen apically. Asci of the Opegrapha-type, ellipsoid to clavate, bitunicate, $30-35 \times$ 7.5-10 $\mu \mathrm{m}$, with apical KI+ blue ring. Ascospores 4-6 per ascus, fusiform, with rounded ends, 6-septate, not constricted at the septa, the median cell usually slightly enlarged, hyaline, $15-18 \times 2.5-3 \mu \mathrm{m}$, perispore up to $0.5 \mu \mathrm{m}$ thick.

Conidiomata not found. 

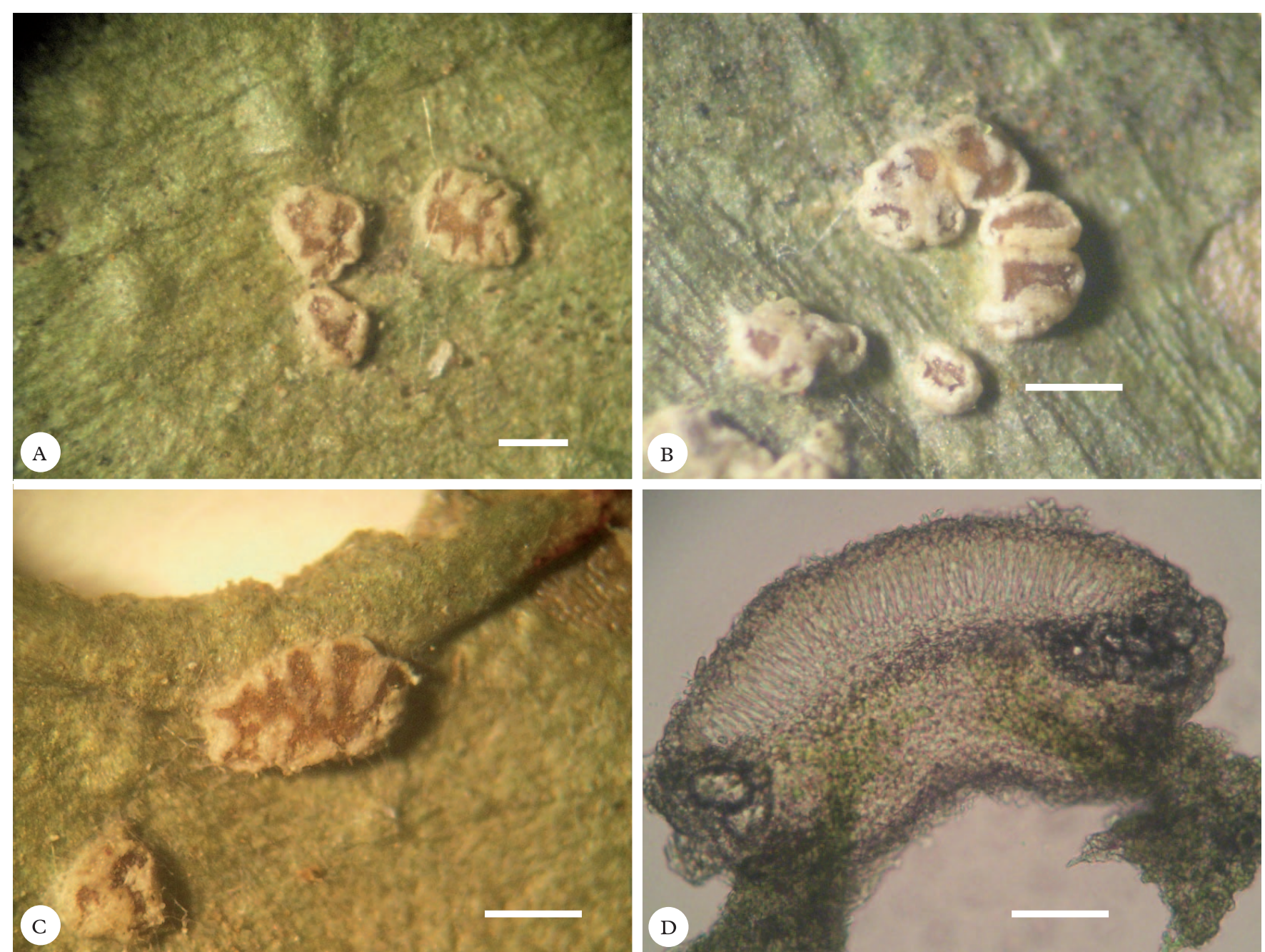

Fig. 1. Enterographa fellhaneroides (holotype). A-C, habit of apothecia; D, section through the apothecium. Scales: A-C $=0 \cdot 2 \mathrm{~mm} ; \mathrm{D}=50 \mu \mathrm{m}$. 

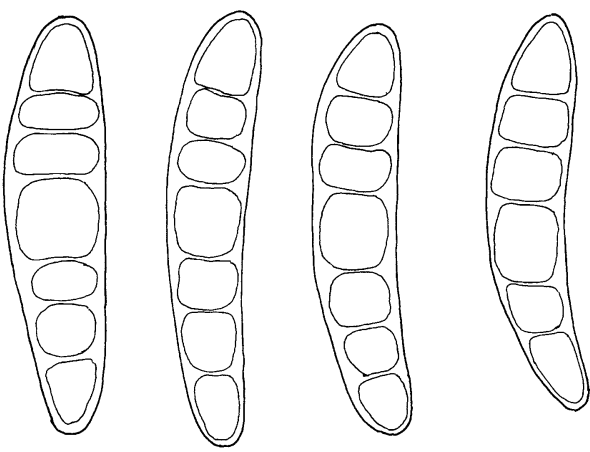

FIG. 2. Enterographa fellhaneroides, ascospores. Scale = $3 \mu \mathrm{m}$. TLC.

Etymology. When we first observed the apothecia of this species, we considered it to be a poorly developed specimen of Fellhanera Vězda until the anatomical features pointed to Enterographa. Hence, the specific epithet is chosen to indicate this resemblance.

Notes. Enterographa fellhaneroides is easily distinguished from other foliicolous species assigned to the genus by its apothecioid or short lirelliform ascomata, with a pale brown disc and a whitish margin, and 6-septate, fusiform ascospores with rounded ends. Its closest related species appears to be the recently described E. brezhonega (Sparrius \& Aptroot 2007), overgrowing the thallus of epiphytic Porina rosei in W France, and reported from the New Forest (S England) on the same host (Hitch 2008). This species is distinguished by its lirelliform, often branched ascomata with a dark brown to black disc. Otherwise both species are very similar, especially the ascospores.

Morphologically, Enterographa fellhaneroides looks similar to $E$. seawardii Lücking \& Henssen, a recently described foliicolous species (in Sparrius 2004) and only known from the Seychelles, because of similar prominent, open, angular-rounded to shortly lirellate ascomata with pale orange discs. However, Enterographa seawardii is easily distinguished by its 7-11-septate, narrowly fusi- form ascospores, 30-40 $\times 3-4 \mu \mathrm{m}$ and its $\mathrm{Pd}+$ yellow (probably psoromic acid) thallus.

Ecology and distribution. Enterographa fellhaneroides is so far known only from Kakamega Forest in Western Kenya in near primary and middle-aged secondary forest fragments. It is a lichenicolous species overgrowing thalli assigned to a Coenogonium sp. (poorly developed but typical apothecia seen). The species is a component of the foliicolous lichen flora of the understorey.

Selected specimens examined. Kenya: Western Province: Kakamega Forest, Kisere fragment $00^{\circ} 22^{\prime} .966^{\prime \prime} \mathrm{N}$, 034 $53^{\prime} .751^{\prime \prime} \mathrm{E}, 1594 \mathrm{~m}$, on living leaves of Chrysophyllum albidum, 2006, Yeshitela 373 (KOBL); Kisere fragment, $00^{\circ} 23^{\prime} .151^{\prime \prime} \mathrm{N}, 034^{\circ} 53^{\prime} .595^{\prime \prime} \mathrm{E}, 1580 \mathrm{~m}$, on living leaves of Teclea nobilis, Dracaena fragrans and Cassipourea ruwenzorensis, 2006, Yeshitela 538, 539 \& 537 (KOBL); Isecheno fragment, 00 $14^{\prime} .522^{\prime \prime} \mathrm{N}$, $034^{\circ} 51^{\prime} .959^{\prime \prime} \mathrm{E}, 1580 \mathrm{~m}$, on living leaves of Cassipourea ruwenzorensis, 2006, Yeshitela 484 \& 493 (KOBL).

\section{Enterographa meklitiae Yeshitela, Eb. Fisch., Killmann \& Sérus. sp. nov.}

Differt ab omnibus speciebus foliicolis generis Enterographa ascomata numerosis punctiformibus in pseudostromata immersis. Enterographa epiphylla differt ab E. meklitiae pseudostromata convexibus punctiformibus ad vix lirellatis vel irregularibus, ascomata nigricantibus et ascosporibus majoribus 6-septatis.

Typus: Kenya, Western Province, Kisere fragment of Kakamega Forest, 00²3'.151" N and 034 ${ }^{\circ} 53^{\prime} .595^{\prime \prime} \mathrm{E}$, $1612 \mathrm{~m}$, on living leaves of Dracaena fragrans, 24 August 2006, Yeshitela 539 (LG-holotypus).

\section{(Figs 3 \& 4)}

Thallus assumed to be absent, ascomata most probably overgrowing the thallus of a non-filamentous Coenogonium which is continuous, smooth, greyish green, photobiont Trentepohlia with cells angular-rounded, 12-20 × 3-7 $\mu \mathrm{m}$.

Ascomata punctiform, $0 \cdot 05-0 \cdot 1 \mathrm{~mm}$ diam., arranged in groups of $8-12(-20)$ in pseudostromata, visible as punctiform (30-50 $\mu \mathrm{m}$ diam.) brownish spots. Pseudostromata rounded or irregular in outline, imarginate, convex to \pm plane, $0 \cdot 2-0.5 \mathrm{~mm}$ diam., up to $75 \mu \mathrm{m}$ high, surface greyish green to whitish, not constricted at base, in section encrusted with large, angular and 

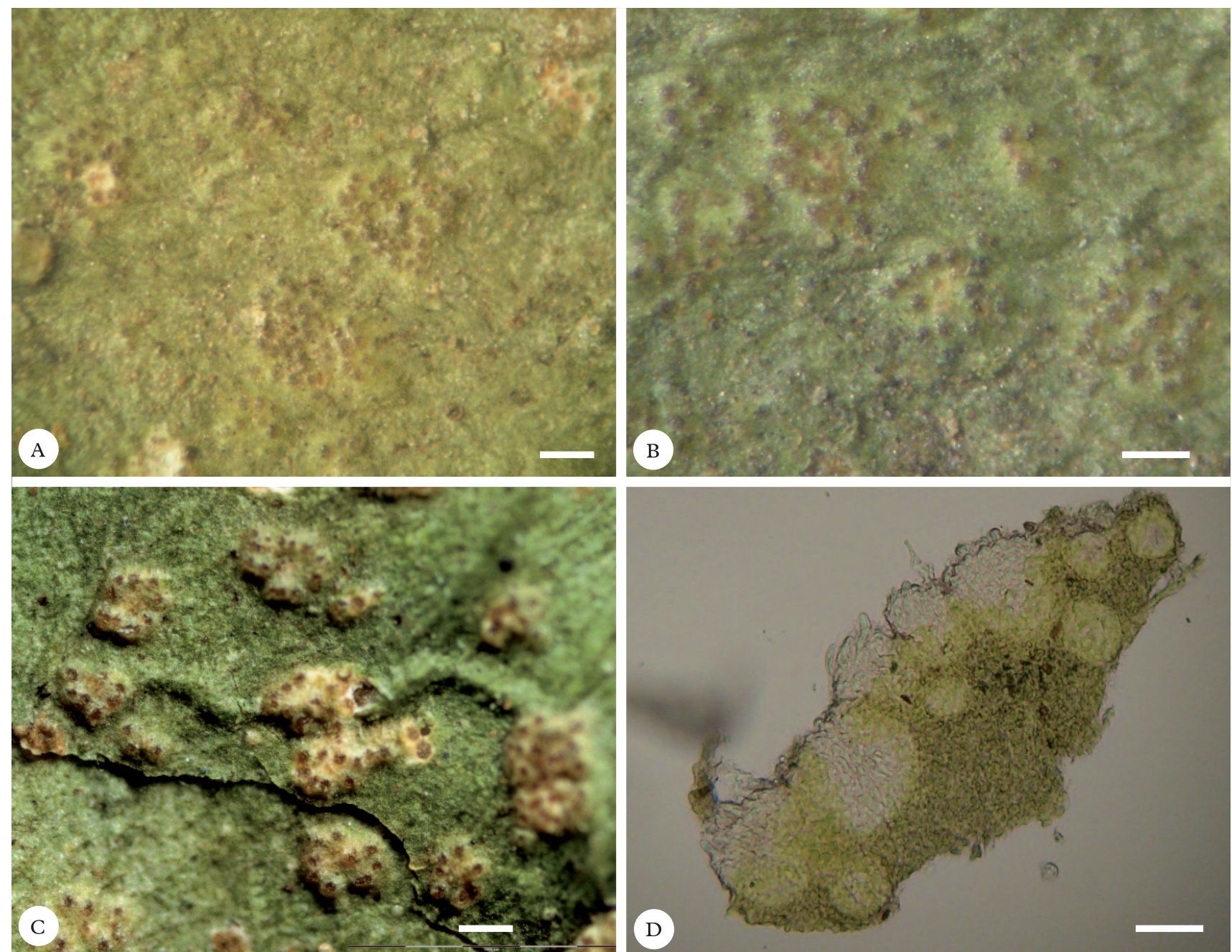

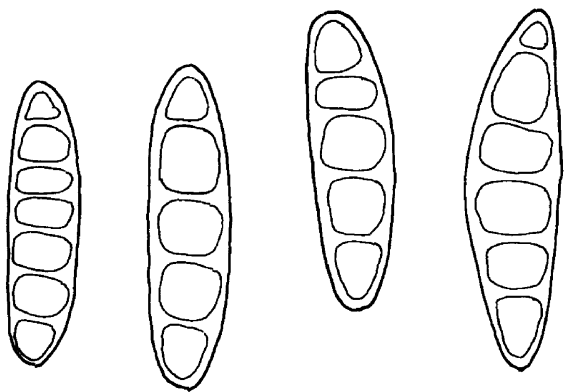

FIG. 4. Enterographa meklitiae, ascospores. Scale $=3 \mu \mathrm{m}$.

hyaline Ca oxalate crystals, K-. Excipulum very thin, c. $5 \mu \mathrm{m}$ wide, pale straw. $H y$ pothecium 10-15 $\mu \mathrm{m}$ high, pale straw, K-, I+ blue rapidly turning red, KI+ blue. Hymenium hyaline, I+ blue rapidly turning red, KI+ blue, 50-60 $\mu \mathrm{m}$ high. Hamathecium of branched and anastomosing paraphysoids, c. $1.5 \mu \mathrm{m}$ thick, not swollen apically. Epithecium indistinct. Asci of the Opegraphatype, ellipsoid to clavate, bitunicate, $37-50 \times$ 7-10 $\mu \mathrm{m}$, with apical KI+ blue ring. Ascospores 4 per ascus, 4-5-septate, ellipsoid to fusiform, with rounded ends, the median cell sometimes slightly enlarged, (13-)15-17 $\times$ 2.5-3 $\mu \mathrm{m}$, not constricted at the septa, perispore $<5 \mu \mathrm{m}$ thick.

Conidiomata not observed. Conidia sometimes produced from tissue inside ascomata (probably the excipulum), simple, c. $2.5 \times 1$ $\mu \mathrm{m}$, bacilliform, hyaline.

Chemistry. No compounds detected by TLC.

Etymology. This species is dedicated to Meklit, the daughter of the first author.

Notes. Enterographa meklitiae can easily be distinguished from other foliicolous species of Enterographa by its numerous, punctiform ascomata immersed in pseudostromata. At first glance, it looks like the conidiomata of the Neotropical Phyllobathelium leguminosae (Cavalc. \& A. A. Silva) Lücking \& Sérus. (see fig. 7E in Lücking et al. 1998). It is close to Enterographa epiphylla (Sérus.) Ertz et al., which overgrows the foliicolous lichen Coenogonium flavicans, and which can be dis- tinguished by its convex pseudostromata, punctiform to slightly lirellate, or irregular, and blackish ascomata, and its larger ascospores $(17-22 \times 3-4.5 \mu \mathrm{m})$ with consistently 6 septa.

Ecology and distribution. Enterographa meklitiae is so far recorded only from Kakamega Forest in Western Kenya. The type locality is a near-primary rain forest dominated by Strychnos usambarensis, Uvariopsis congensis, Pouteria altissima (=Aninngeria altissima), Cassipourea ruwensorensis, Dracaena fragrans, Funtumia africana, Diospyros abyssinica, and Heinsenia dieverilleoides. There is no strong evidence that it is a lichenicolous species overgrowing the thallus of a non-filamentous Coenogonium, but it is assumed to have such an ecology. Indeed, its 'thallus' is very similar to that of Enterographa fellhaneroides (in one collection, both species grow over the same thallus), and all genuinely lichenized foliicolous species of Enterographa have Phycopeltis as photobiont (Sparrius 2004).

Selected specimens examined. Kenya: Western Province: Kakamega Forest, Isccheno, $00^{\circ} 14^{\prime} .522^{\prime \prime} \mathrm{N}$, $034^{\circ} 51^{\prime} .959^{\prime \prime} \mathrm{E}, 1580 \mathrm{~m}$, on living leaves of Cassipourea ruwensorensis, 2006, Yeshitela 484 (KOBL).

\section{Discussion}

As with most other genera in the Roccellaceae, the delimitation of the genus Enterographa requires further studies, hopefully based on molecular sequences from several genes. Nevertheless, the four species described or discussed in this paper (Enterographa epiphylla, E. brezhonega, E. fellhaneroides and E. meklitiae) characterized by their lichenicolous habit on thalli with Trentepohlia as photobiont and 4(-6) fusiform ascospores with rounded ends per ascus, an even number of septa and the median cell slightly enlarged, seem to be closely related. It is premature to suggest the taxonomic recognition of that group but equally, its inclusion in Enterographa, Plectocarpon or Sclerophyton is not fully satisfactory.

We wish to thank very warmly Dr. Damien Ertz from the National Botanical Garden of Belgium for important 
comments and suggestions; we further thank both anonymous referees for their interesting suggestions. The study was funded by the German Ministry of Education and Research (BMBF) within the BIOTA East project E04 (LC0625C1). The first author was funded by the German Catholic Academic Exchange Service (KAAD). Thanks are also due to the Kenya Wildlife Service (KWS) in Nairobi for a research permit in Kakamega Forest. We would also like to thank the staff of the East African Herbarium (EA) at the National Museums of Kenya (NMK), Nairobi and the Kenyan Wildlife Service field office in Kakamega for logistic support.

\section{REFERENCES}

Althof, A. (2005) Human impact on flora and vegetation of Kakamega Forest, Kenya. Ph.D. Thesis, University of Koblenz-Landau.

Aptroot, A., Diederich, P., Sérusiaux, E. \& Sipman, H. J. M. (1995) Lichens and lichenicolous fungi of Laing Island (Papua New Guinea). Bibliotheca Lichenologica 57: 19-48.

Aptroot, A., Saipunkaew, W., Sipman, H. J. M., Sparrius, L. B. \& Wolseley, P. A. (2007) New lichens from Thailand, mainly microlichens from Chiang Mai. Fungal Diversity 24: 75-134.

Cáceres, Marcela Eugenia da Silva (2007) Corticolous crustose and microfoliose lichens of northeastern Brazil. Libri Botanici 22: 1-168.

Ertz, D., Christnach, C., Wedin, M. \& Diederich, P. (2005) A world monograph of the genus Plectocarpon (Roccellaceae, Arthoniales). Bibliotheca Lichenologica 91: 1-155.

Farwig, N., Böhning-Gaese, K. \& Bleher, B. (2006) Enhanced seed dispersal of Prunus africana in fragmented and disturbed forests. Oecologia 147: 238-252.

Grube, M. (1998) Classification and phylogeny in the Arthoniales (lichenized Ascomycetes). Bryologist 101: 377-391.

Herrera-Campos, M. A. \& Lücking, R. (2002) The foliicolous lichen flora of Mexico. I. New species from Los Tuxtlas Tropical Biology Station, Veracruz. Lichenologist 34: 211-222.

Hitch, C. (2008) New, rare or interesting lichens. British Lichen Society Bulletin 102: 24-38.

Jagadeesh Ram, T. A. M., Sinha, G. P., Singh, K. P. (2008) New species and new records of Enterographa (Roccellaceae) from India. Lichenologist 40: $415-418$.

Lücking, R. (1991) Neue Arten foliikoler Flechten aus Costa Rica, Zentralamerika. Nova Hedwigia 52: 267-304.

Lücking, R. \& Matzer, M. (1996) Ergänzungen und Verbesserungen zur Kenntnis der foliikolen Flechtenflora Costa Ricas. Die Familie Opegraphaceae. Nova Hedwigia 63: 109-144.
Lücking, R., Sérusiaux, E., Maia, L. C. \& Pereira, C. G. (1998) A revision of the names of foliicolous lichenized fungi published by Batista and coworkers between 1960 and 1975. Lichenologist 30: 121-191.

Lücking, R., Wirth, V., Ferraro, L. I. \& Cáceres, M. E. S. (2003) Foliicolous lichens from Valdivian temperate rain forest of Chile and Argentina: evidence of an austral element, with the description of seven new taxa. Global Ecology \& Biogeography 12: 21-36.

Matzer, M. (1996) Lichenicolous ascomycetes with fissitunicate asci on foliicolous lichens. Mycological Papers 111: 1-202.

Myllys, L., Lohtander, K., Källersjö, M. \& Tehler, A. (1999) Applicability of ITS data in Roccellaceae (Arthoniales, Euascomycetes) phylogeny. Lichenologist 31: 461-476.

Santesson, R. (1952) Foliicolous lichens I. A revision of the taxonomy of the obligately foliicolous, lichenized fungi. Symbolae Botanicae Upsalienses 12(1): $1-590$.

Sérusiaux, E. (1984) New species or interesting records of foliicolous lichens. Mycotaxon 20: 283-306.

Sparrius, L. B. (2004) A monograph of Enterographa and Sclerophyton. Bibliotheca Lichenologica 89: 1-141.

Sparrius, L. B. \& Aptroot, A. (2007) A new lichenicolous Enterographa species from Brittany (France). Lichenologist 39: 315-317.

Sparrius, L. B. \& Björk, C. R. (2008) Enterographa oregonensis (Roccellaceae), a new foliicolous species from the northwest coast of North America. Bryologist 111: 487-489.

Sparrius, L. B., Saipunkaew, W., Wolseley, P. A. \& Aptroot, A. (2006) New species of Bactrospora, Enterographa, Graphidastra and Lecanographa from northern Thailand and Vietnam. Lichenologist 38: 27-36.

Tattersfield, P., Seddon, M. B. \& Lange, C. N. (2001) Land-snail faunas in indigenous rainforest and commercial forestry plantations in Kakamega forest, western Kenya. Biodiversity and Conservation 10: 1809-1829.

Tehler, A. (1990) A new approach to the phylogeny of euascomycetes with a cladistic outline of Arthoniales focusing on Roccellaceae. Canadian fournal of Botany 68: 2458-2492.

Tehler, A., Lohtander, K., Myllys, L. \& Sundin, R. (1997) On the identity of the genera Hubbsia and Reinkella (Roccellaceae). In Lichen Studies Dedicated to Rolf Santesson (L. Tibell., \& I. Hedberg, eds): 255-265. Symbolae Botanicae Upsalienses, Acta Universitatis Upsaliensis, Uppsala.

Tehler, A. \& Irestedt, M. (2007) Parallel evolution of lichen growth forms in the family Roccellaceae (Arthoniales, Ascomycota). Cladistics 23: 1-23.

Vězda, A. (1975) Foliicole Flechten aus Tanzania. Folia Geobotanica Phytotaxonomica, Praha 10: 383-432. 
